Bryn Mawr College

Scholarship, Research, and Creative Work at Bryn Mawr College

Graduate School of Social Work and Social

Graduate School of Social Work and Social

Research Faculty Research and Scholarship

Research

2007

\title{
Devolution, Discretion, and the Effect of Local Political Values on TANF Sanctioning
}

Richard C. Fording

Joe Soss

Sanford F. Schram

Bryn Mawr College, sschram@brynmawr.edu

Let us know how access to this document benefits you.

Follow this and additional works at: http://repository.brynmawr.edu/gsswsr_pubs

Part of the Social Work Commons

\section{Custom Citation}

Fording, Richard C., Joe Soss, and Sanford F. Schram. "Devolution, Discretion, and the Effect of Local Political Values on TANF Sanctioning." Social Service Review 81 (2007): 285-316.

This paper is posted at Scholarship, Research, and Creative Work at Bryn Mawr College. http://repository.brynmawr.edu/gsswsr_pubs/6

For more information, please contact repository@brynmawr.edu. 


\title{
Devolution, Discretion, and the Effect of Local Political Values on TANF Sanctioning
}

\author{
Richard C. Fording \\ University of Kentucky \\ Joe Soss \\ University of Wisconsin-Madison \\ Sanford F. Schram \\ Bryn Mawr College
}

\begin{abstract}
One of welfare reform's most significant consequences is the devolution of policy-making authority from the federal government and states to local governments and frontline workers. What is perhaps less often appreciated is that devolution of authority to state governments has been accompanied by a significant decentralization of policy-making authority within states. As a result, prior research has not given sufficient attention to local political context as a factor shaping program implementation. This article examines the effect of local political values on the use of sanctions to penalize welfare recipients. Analyzing administrative data from the Florida Department of Children and Families for over 60,000 welfare clients, we find that there is a statistically significant amount of local variation in sanctioning rates across the state of Florida, even after controlling welfare clients' characteristics. Local sanctioning patterns are systematically related to selected characteristics of local communities, including their ideological orientations.
\end{abstract}

In 1996, the federal government made large-scale changes to income assistance, replacing the entitlement program Aid to Families with Dependent Children (AFDC) with the Temporary Assistance for Needy Families (TANF) program. Under TANF, state policy makers have significant freedom to craft their own approaches to public assistance (Nathan 1996). It is now generally acknowledged that states responded to this new freedom in diverse ways that systematically reflect their social,

Social Service Review (June 2007).

(C) 2007 by The University of Chicago. All rights reserved.

0037-7961/2007/8102-0004\$10.00 
economic, and political characteristics (Soss et al. 2001; Gais and Weaver 2002; Fellowes and Rowe 2004).

What is perhaps less often appreciated about welfare reform under TANF is that devolution of authority from the federal government to state governments has been accompanied by a significant decentralization of policy-making authority within states (Gainsborough 2003). The TANF program's emphasis on flexible services and sanctioning virtually ensures that decision making is pushed downward to local implementers, including case managers, who serve as the primary streetlevel bureaucrats in the new world of welfare service delivery (Ridzi 2004; Riccucci 2005; Lurie 2006). However, many states further expand local discretion in TANF implementation by pursuing second-order devolution; that is, some states formally transfer control to county governments or local governance boards (Nathan and Gais 1999). Decentralization is further enhanced by the growing reliance on contract agencies for service delivery (Dias and Maynard-Moody 2007). Although there is little systematic data on the extent of second-order devolution in welfare policy, a recent study estimates that by 2001, at least 20 states engaged in either "slight" or "significant" amounts (Gainsborough 2003, 607-8).

Advocates of welfare decentralization argue that devolution promotes TANF goals by fostering innovation and flexibility in meeting client needs (see, e.g., Eggers and O'Leary 1995). This is critical to TANF's success, supporters assert, because employment barriers are most effectively identified and addressed by local decision makers who best understand the needs of their poor and the resources available to them in the community (Weissert 2000; Gainsborough 2003). However, the increase in local discretion that accompanies decentralization enables local policy makers, agency managers, and frontline workers to use their discretion for other purposes, including the advancement of political goals. Indeed, the collective findings from a large body of research suggest that implementation outcomes often reflect the political values of local policy makers, agency staff, and the local community (e.g., Lipsky 1978; Goggin et al. 1990). In light of this research, one might expect that the use of local discretion under TANF is driven as much by the local political culture as by the unique needs of the low-income residents in the community.

Many studies evaluate the effects of decentralization in welfare reform by examining how implementation may be affected by dynamic interactions among incentives, organizational forms, cultures, and welfare agency personnel (Meyers, Riccucci, and Lurie 2001; Ewalt and Jennings 2004). Although most of these studies find that local events and conditions affect implementation, they give little consideration to the roles of ideology and local political context. This article contributes to the literature by examining the effect of local political values on one of the 
most consequential aspects of welfare reform: the use of sanctions to penalize recipients who fail to fulfill TANF requirements. Although a number of studies effectively examine the determinants of sanctioning, they have almost exclusively focused on client characteristics and ignored the possibility that variation in sanctioning occurs due to the effects of the local political environment (for a review, see Meyers et al. [2006]; for an example, see Wu et al. [2006]). The analysis that follows addresses two specific questions. First, to what extent has welfare decentralization led to variation in the use of TANF sanctioning across local jurisdictions operating under the same sanction policy? Second, are local differences in sanctioning solely a function of variation in client characteristics, or is the use of sanctioning also influenced by the local implementation environment and, especially, by the local political context?

These questions are answered by examining sanctioning outcomes in the state of Florida, which stands as a leader in welfare decentralization and second-order devolution. The analysis is based on administrative data for over 60,000 TANF clients in Florida. These data are used to examine how individual sanction outcomes are related to individual client traits, local social and economic conditions, and the local political environment.

\section{Welfare Reform and Sanctioning under TANF}

Sanctions have long been used by caseworkers to encourage compliance with state welfare rules. Over the past decade, however, sanctions have come to play a more prominent role in welfare implementation; compared to the AFDC program, the TANF program compels clients to face stricter work requirements, narrower exemption criteria, a greater number of behaviors subject to sanction, and stronger penalties for noncompliance (Hasenfeld and Powell 2004). Most analysts agree that sanctions are a linchpin of the successful effort to transform welfare from a system focused on providing cash benefits (AFDC) to one focused on the promotion of work norms (TANF; see Pavetti et al. 2004).

Federal legislation requires that TANF clients be subject to a reduction in benefits for failure to follow a number of different program rules (U.S. Public Law 104-193 [1996]). Under TANF, states have a range of options in determining exactly how benefits should be reduced. The most important of these options enable states to decide (1) whether to reduce the benefit for the eligible adult, all adults in a family, or the entire family and (2) whether and when to impose a partial or full reduction of benefits. Seventeen states rely on the strictest combination of these choices, enforcing what is referred to as an "immediate fullfamily sanction" (Pavetti, Derr, and Hesketh 2003, 2). In these states, the entire TANF family is immediately removed from the TANF rolls at the first instance of noncompliance. Eighteen states use a "gradual full- 
family sanction," which potentially has the same effect, but it is applied only after continued noncompliance (Pavetti et al. 2003, 3). The remaining states enforce what is known as a "partial sanction," which results in a partial reduction of benefits (usually affecting only the portion of the grant awarded to adults; Pavetti et al. [2003], 2).

Studies using a variety of dependent variables suggest that sanctioning has important effects on the size and characteristics of the TANF caseload. In one of the first relevant studies in the TANF era, Heidi Goldberg and Liz Schott (2000) estimate that between 1997 and 1999, nearly 500,000 families lost benefits due to sanctions. This represents a quarter of the caseload reduction for that period. Other studies that focus on selected states also find the incidence of sanctioning is quite high (for a review, see Pavetti et al. [2004]). Given these estimates, it is not surprising that many state-level studies find high caseload reductions among states with strict policies. States with the strictest sanctioning policies experienced a caseload reduction that is as much as 25 percent greater than those reported by states with the least stringent policies (Rector and Youssef 1999; Mead 2000).

Several studies use surveys of TANF recipients or state administrative data to examine the characteristics of sanctioned families. The findings converge on the conclusion that sanctioned clients tend to exhibit the characteristics of long-term welfare recipients (Pavetti et al. 2003; Wu et al. 2006). Studies find that the probability of being sanctioned is related to a client's race, marital status, age, family size, education level, and job experience (Born, Caudill, and Cordero 1999; Koralek 2000; Westra and Routely 2000; Mancuso and Lindler 2001; Hasenfeld, Ghose, and Hillesland-Larson 2002; Kalil, Seefeldt, and Wang 2002). If the overall incidence of sanctioning is also considered, it follows that sanctioning practices greatly affect the characteristics of the TANF population.

The literature, however, pays surprisingly little attention to the decentralized implementation processes that are at the heart of welfare reform. To be sure, there is some evidence that, within states, sanction rates vary among locales with different social characteristics, political environments (Keiser, Meuser, and Choi 2004), sanctioning philosophies, and case processing procedures (Maloy et al. 1998; Born et al. 1999; Koralek 2000). These few studies notwithstanding, the consequences of dispersed local implementation remain a blind spot in understanding sanction processes and outcomes (Pavetti et al. 2003).

\section{Devolution, Discretion, and the Implementation of TANF Sanctions}

The central argument here is that welfare reform has been accompanied by a significant and, in recent decades, unprecedented devolution of 
policy-making discretion to local actors. Second-order devolution produces significant and systematic variation in the use of TANF sanctions by local actors within states. The variation reflects the exercise of discretion by two sets of actors in the TANF implementation process: (1) local TANF policy makers, whose discretion in TANF implementation has increased significantly in many states due to second-order devolution, and (2) agency administrators and their case managers, who are charged with the responsibility of monitoring client behavior and initiating sanctions if TANF rules are violated.

\section{Second-Order Devolution}

In general, second-order devolution takes two forms. The most common form is exemplified in the actions of 14 states, which devolve policy authority to county governments (Gainsborough 2003). Ten of these states previously shared AFDC administrative duties with counties. This prior sharing of authority may have encouraged policy makers in these states to devolve policy authority for TANF down to the county level. These 14 states vary in the types of duties they pass down to counties. In states with the greatest amount of second-order devolution, counties gain substantial control over spending (through block grants). They enjoy broad discretion over the use of TANF work requirements, sanctions, time limits, and one-time diversion payments (Gainsborough 2003).

Welfare policies in six other states exemplify the second form of second-order devolution. These states grant policy authority to local or regional governing boards rather than to counties. In all six states, welfare services have been linked to state workforce development programs that operate under the Workforce Investment Act (WIA; U.S. Public Law 105-220 [1998]). Welfare and workforce development programs are implemented through one-stop centers run by public or private organizations, including for-profit providers, that are contracted by regional workforce boards (RWBs) to administer these programs. These boards are mandated by WIA. Their membership comprises both public and private officials. The exact rules for board composition vary from state to state, but most of the six states require that at least half of the board's members come from the local business community (Gainsborough 2003). These boards have power over TANF policy, but the extent of that power varies. According to Juliet Gainsborough (2003), Florida, Michigan, and Texas cede significantly greater amounts of authority to their RWBs than do Arkansas, Tennessee, and Utah.

Agency and Caseworker Discretion

Frontline agencies and their staff have always had broad discretion in implementing welfare policy. This discretion has changed under TANF because the program expanded the number of rules governing client 
behavior and the proportion of clients to which these rules must now be applied. Whether this represents an increase in discretion for either the management of agencies or their case managers is not clear. Agencies must implement policy consistent with its stated objectives; agencies contracted to provide services must fulfill the terms of their contracts. Managers, however, can find different ways to structure agency operations to achieve program objectives and meet performance goals (Ridzi 2004; Riccucci 2005; Lurie 2006). Decentralization can enhance this sort of discretion. Decentralization can also increase variation across organizations, as agencies vary in their capacity to implement policy competently.

Within agencies, caseworkers can exercise additional discretion (Lipsky 1980). Three sources of constraint operate on caseworkers but in less than definitive ways. First, supervision may be used to limit or guide caseworker discretion. Under welfare reform, such supervision may have increased in states such as Florida, where state-of-the-art management information systems facilitate monitoring of caseworkers and their clients (Shaw et al. 2006). Caseworkers, however, rarely operate under the direct watch of supervisors (Prottas 1979; Lipsky 1980). Workers often handle cases that are too complex and idiosyncratic to fit neatly under a supervisor's a priori directive, and they process cases at rates that make continual consultation impractical (Maynard-Moody and Musheno 2003).

Second, administrative rules place broad limits on caseworkers, but such rules cannot be designed to cover all conceivable situations, nor can a rule "itself step forward to claim its own instance" (Hart 1961, 123). Choices must be made about how and when to apply a given rule, and as the number of rules grows, so too grows the scope of frontline decision making. Rather than eliminating discretion, "a profusion of rules can lead to greater freedom because . . the bureaucrat must choose which rules are appropriate in the present [case]" (Feldman 1992, 166; see also Lipsky 1980, 14).

Third, program clients may create a possible check on caseworker discretion because clients have the potential to use formal or informal means to limit decisions contrary to their interests. Here again, however, theory and evidence suggest that client action is a weak constraint. Political economy approaches to social work theory argue that welfare clients occupy a dependent position in a relationship defined by unequal control of power resources (Hasenfeld 1987). To be sure, clients are active participants in welfare interactions, and they do what they can to subtly influence outcomes, but field research suggests that welfare clients feel a keen sense of dependence on case managers; most clients report that they avoid explicitly opposing caseworkers because such opposition is seen as risky and ineffective (Soss 2000). Under the TANF program, moreover, client benefits are no longer an entitlement, and clients have lost some of the formal rights of appeal that they had under AFDC. 
These changes in policy seem likely to further weaken clients' abilities to impose limits on caseworker discretion (Mink 2002).

In light of the weakness of these constraints on both frontline agencies and their caseworkers, it has become conventional wisdom that "discretion is inevitable" in street-level work (Maynard-Moody and Musheno 2000, 329). Decision making on the front lines (whether by agency managers or their caseworkers) is widely recognized as a political process that elaborates, transforms, and sometimes subverts the policy intentions of lawmakers (Meier 2000). Such discretion may serve as an entry point for unjust and unequal treatment or, alternatively, may permit the tailoring of more equitable and humane responses than the rules would lead one to expect (Keiser 1999, 88-89). In either case, empirical research suggests that frontline discretion can produce wide variation even in implementation of a federal program (Keiser and Soss 1998) or within a highly centralized state welfare program (Riccucci 2005).

Despite such variation, it remains unclear whether agency manager or caseworker discretion has increased under TANF and whether their discretionary actions are affecting the implementation of sanctions. Yet existing research appears to indicate that there is ample opportunity for the exercise of discretion in sanction implementation (see Meyers et al. 2006). This is clearly the case in states that delegate important sanction policy decisions to local governing bodies and their provider agencies. However, in the most comprehensive review of TANF sanction research to date, LaDonna Pavetti and associates $(2003,6)$ find that even when TANF offices operate under a common set of state guidelines, local actors are able to exercise considerable discretion at a number of key points in the sanction implementation process. Pavetti and associates (2003) identify six examples of these key points in the sanctions process. These key points occur when (1) informing clients of TANF rules and the consequences for breaking them; (2) assessing client needs and identifying those clients who are unable to participate in regular work activities; (3) monitoring participation in required activities; (4) granting good-cause exceptions from participation in required work activities; (5) initiating sanctions, including the method and timing of contact to inform clients of an impending sanction; and (6) reengaging clients, including the process for lifting a sanction. ${ }^{1}$

All of these points in the implementation process offer opportunities for policy makers, agency managers, and caseworkers to exercise discretion. Yet, perhaps the most important moment of flexibility is that at which these local actors interpret guidelines governing the application of good-cause exceptions. The federal government requires that states excuse single custodial parents from TANF work requirements if they cannot find adequate child care. States also regularly excuse violations of work requirements if the client lacks transportation or is ill. In addition, most states grant good-cause exceptions due to circumstances 
beyond the client's control. Under second-order devolution, local policy makers often determine the guidelines for deciding whether an exemption should be granted; local agency officials and their caseworkers get to interpret how to apply those guidelines. Along with other opportunities for exercising discretion, good-cause exception policies offer local policy makers and administrators significant influence over when sanctions are applied. As a consequence of this local discretion, significant differences should occur in the implementation of sanctions across local communities.

\section{Politics and the Implementation of Sanctions}

Theories of organizational culture emphasize that bureaucratic norms and understandings should not be seen as autonomous, insider worldviews disconnected from their social milieus; rather, organizational cultures derive from, elaborate upon, and reflect the commonsense understandings of the broader communities in which they are embedded (Feldman 1989; Herzfeld 1992; Martin 1992). Local environments may affect organizational operations through democratic pressures, policy makers may respond to local social conditions and needs, or officials may share the political values of the community at large. Consistent with this thinking, findings in several studies indicate that local public policy implementation is influenced by the local political environment (e.g., Goggin et al. 1990; Weissert 1994; Cho et al. 2005). This should be no less true of local implementation of TANF sanctions, especially in states that devolved significant authority to the local level.

The current study's conceptualization of the political environment is based on the classic liberal-conservative dimension, which state-level studies of AFDC and TANF have repeatedly shown to be an important determinant of support for welfare generosity (e.g., Fording 1997; Soss et al. 2001; Barrilleaux, Holbrook, and Langer 2002). In states that assign significant control to local entities, the political characteristics of local environments might affect sanctioning rates in different ways through the actions of three important local actors in the TANF implementation process: case managers, local TANF policy makers and administrators, and local advocacy groups.

First, local political culture may influence the sanctioning decisions of case managers who share the political values of the community (Riccucci 2005). Survey research consistently finds that, compared to conservatives, liberals are generally more likely to attribute the causes of poverty to structural explanations and are therefore more likely to support public assistance (Cook and Barrett 1992). Accordingly, one would expect case managers in liberal environments to be more sympathetic to TANF clients in interpreting and applying TANF rules (Morgen 2001). Case managers in conservative environments, however, may be more 
likely to attribute poverty to individual shortcomings and therefore may be less sympathetic to TANF clients who have fallen out of compliance with TANF rules (Keiser et al. 2004). Thus, case managers in conservative environments will be more willing to issue sanctions to TANF clients than are case managers in liberal environments.

Second, in a decentralized policy-making environment, the political orientations of local environments may generate differences among the key decision makers of local agencies; those individuals are responsible for interpreting state sanction policies and guiding the activities of local case managers (Cho et al. 2005). County government officials in some states may have a significant effect on sanctions policy. In states that merged TANF and workforce development programs, the local workforce board, their contracted service providers, and the caseworkers in such agencies may have significant influence in interpreting sanction policies and over how the policies are implemented (Gainsborough 2003). It is expected that, in both settings, the degree of local conservatism will be positively related to stringency in the local operating procedures that govern sanctioning. Local conservatism thus may also lead to high sanction rates.

Third and finally, local political environments may influence sanction rates through their effects on the presence and strength of local advocacy groups for the poor. Such groups may indirectly influence local operating procedures through advocacy aimed at local TANF policy makers. In some states, groups may exert influence by lobbying local workforce boards or even by gaining seats on boards. In addition, contacts with liberal welfare advocacy groups provide welfare clients with crucial sources of information and support (Handler 1992). Field research suggests that such support from advocacy groups can positively affect client-worker interactions (Soss 2000). Thus, whether the effect of the local political environment is exerted through the actions of local policy makers, administrators and caseworkers, or advocacy groups, the level of local conservatism should be positively related to local sanctioning rates.

\section{Research and Design}

\section{Case Selection: Why Study Florida?}

Florida is the setting for this study because it offers a superb opportunity to examine relevant policy arrangements in a strong form (on the logic of case selection, see Ragin [2000]; Yin [2003]). The state stands out for three reasons.

First, Florida pursues one of the country's strongest forms of secondorder devolution, blending transfers of authority to local actors, program integration, and widespread privatization. Since July 1, 2000, Flor- 
ida has provided TANF and WIA program services through one-stop centers, and these programs are subject to integrated implementation. A statewide public-private partnership called Workforce Florida Inc. (WFI) oversees the workforce system. It delegates local authority for these programs to RWBs that include representation from public and private interests, including governmental offices and local employers. These RWBs are responsible for strategic planning, policy development, contracting, and oversight of local one-stop delivery systems. Frontline services are provided by independent contractors. Regional workforce boards award service contracts to public, nonprofit, and for-profit providers. The Florida Department of Children and Families (DCF), a conventional state agency, receives the federal TANF block grant and maintains responsibility for eligibility determination. Florida is otherwise a standout among American states for its strong emphasis on local control and privatization within an integrated work-oriented policy system (Botsko, Snyder, and Leos-Urbel 2001, 7).

Second, Florida provides an ideal case for studying sanctions. After 1996, Florida adopted "some of the strictest time limits and work requirements in the nation," broadening the pool of clients subject to sanctions by permitting "few possibilities for exemptions" (Botsko et al. 2001, 4). The penalties associated with sanctions in Florida are very strict. Sanction policies vary across the states in the type of penalty imposed, and Florida's policies are among the strictest, resulting in an immediate, full-family loss of TANF benefits as well as a reduction of food stamp benefits to the fullest extent permitted by federal law (6). Although cross-state comparisons are complicated by the diverse methods that states use to calculate sanction frequency, the current analysis of Florida administrative data suggests that Florida employs sanctions at an extremely high rate. Indeed, these data indicate that the Florida DCF identified sanctions as the most common cause of TANF case closings in fiscal year 2003. Sanctions accounted for 31 percent of closings; only 21 percent of cases were closed due to increased earnings.

Finally, Florida is an ideal choice for the current study because there is much variation in the state's local political environments. The local economic and social conditions are similarly diverse in Florida. Florida's heavy emphasis on sanctioning, its decentralized approach to welfare reform, and the variation in political, social, and economic characteristics combine to make the state an ideal setting for a study of the joint effects of these characteristics on local sanction rates.

\section{Data and Hypotheses}

Event history analysis is used to examine which factors best predict the imposition of sanctions. The sample consists of individual-level administrative data on all adults who received TANF in Florida between January 
2001 and December 2002. These data are supplemented with contextual data that measure variation in the local implementing environment across 66 of the state's 67 counties. ${ }^{2}$ The combined data are used to estimate event history models of TANF sanctioning. A dichotomous dependent variable indicates whether a client was sanctioned. The independent variables include individual-level measures that capture client effects and county-level measures that capture community-context effects. ${ }^{3}$ A number of variables control for variation in clients' individual characteristics. These variables include clients' gender, age, marital status, number of children, the age of the youngest child, wage income (during the quarter prior to the observation), and education level. A client's race and ethnicity are controlled by identifying clients as belonging to one of three mutually exclusive racial and ethnic group combinations: black, Hispanic, and white (non-Hispanic) ${ }^{4}$ Past research indicates that these control variables are important predictors of sanctioning (Born et al. 1999; Koralek 2000; Mancuso and Lindler 2001; Hasenfeld et al. 2002; Kalil et al. 2002; Wu et al. 2006).

The effects of the local political environment are captured through a measure that conceptualizes local political ideology in traditional liberal-conservative terms. Estimating the relationship between ideology and sanctioning at the local level poses a difficult challenge due to the lack of a readily available measure of local ideology. In light of this, the most common strategy in measuring local ideology focuses on county partisanship as it is reflected in election returns (e.g., Keiser et al. 2004; Cho et al. 2005). However, it is well known that partisanship tends to be imperfectly related to political ideology (Miller 1999). Therefore, this common strategy is likely to introduce measurement error into the analysis. As an alternative to relying on local partisanship, this research employs an original measure of local political ideology. Election results are coded in each county for 18 ideologically relevant constitutional amendments that appeared on the ballot throughout the entire state between 1996 and 2004. ${ }^{5}$ Scores from a factor analysis of support for all 18 amendments are used to create an index of county ideology. The index is scaled to range from zero to one, with zero representing the most liberal county (Gadsen) and one representing the most conservative county (Clay).

The measure of county conservatism is validated in two ways. First, it is correlated with local partisanship. Validity is supported because the simple correlation between the measure of county conservatism and a measure of the average Republican vote share in recent presidential elections is reasonably strong at $0.65(p<.05, N=67){ }^{6}$ Second, the measure is validated against measures of liberal-conservative self-identification. This is accomplished by merging results from two statewide surveys that measure liberal-conservative self-identification at the individual level. County means across these survey responses are calculated 


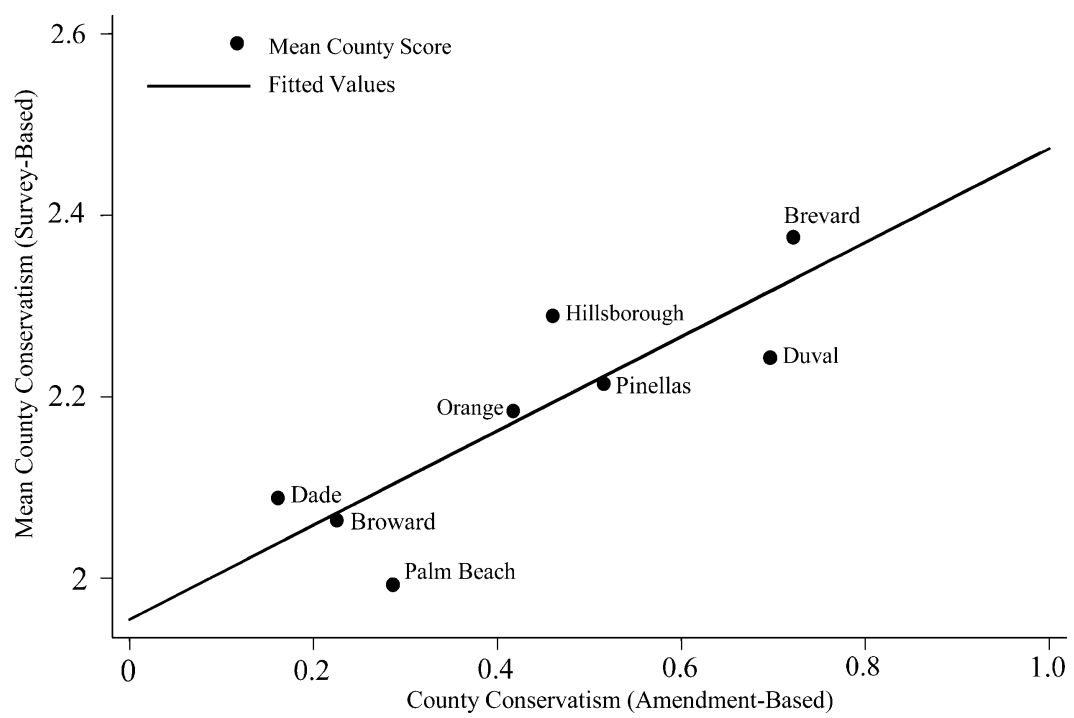

FIG. 1.-Relationship between county conservatism index and average county conservative identification (survey based).

for the eight counties with at least 50 respondents represented in the merged sample. The means are then correlated with the measure of local conservatism. ${ }^{7}$ The relationship between the amendment-based measure of county conservatism and the survey-based measure for these eight counties is presented in figure 1 . As the figure shows, the conservatism index corresponds well with the survey-based measure; the two measures are correlated at 0.85 . There is, thus, good evidence that the measure of local ideology is valid.

The local racial context is also examined. Studies of racial politics and policy outcomes often find that the racial context affects racially relevant policy outcomes. Such effects are possibly due to a number of factors, including a sense of racial threat felt by the white majority (Key 1949; Blalock 1967) and the effects of increased minority political power (Keech 1968). Accordingly, the analyses include measures of the percentages of county residents who are black or Hispanic. If Lael Keiser and associates' (2004) results for Missouri offer any guidance, county sanction rates will be inversely related to the share of county residents who are nonwhite.

Several contextual measures capture the effects of local labor market conditions on sanctions. First, if employment opportunities are relatively numerous and attractive, TANF clients may be likely to work enough hours to avoid falling out of compliance with TANF rules. Second, if jobs are scarce or unattractive, local administrators and case managers 
may be sympathetic to TANF clients who fail to meet work requirements and may resist stringent enforcement of TANF rules. The measures of employment opportunities include the county unemployment rate, the county poverty rate, the level of urbanization (as measured by total county population), and the annual local wage in food service and drinking establishments. ${ }^{8}$

A measure of the local TANF caseload is also included. This measures the number of TANF-receiving adults per 100,000 county residents. As the caseload size grows, all else equal, administrative pressures to reduce the caseload may increase, resulting in a rise in sanctioning. But it also is possible that if the caseload size increases relative to the number of case managers, individual case managers may have less time to closely monitor TANF clients for violations of rules, thus resulting in a decline in the rate of sanctioning. Possible seasonal effects in sanctioning are controlled by including dummy variables for each calendar month.

\section{Results}

Statewide Sanctioning Rates

Florida, along with many other states, employs immediate, full-family sanctions to penalize clients who fall out of compliance with TANF requirements. An inspection of statewide sanctioning data suggests that sanctions are rather frequently enforced in Florida. The aggregate trends in sanctioning over time are presented in figure 2. This figure suggests that the number of sanctions issued each month was relatively stable between 2000 and 2004. There are occasional fluctuations around a mean of about 3,200 sanctions per month. Figure 2 provides some perspective, displaying the number of TANF exits that occurred for reasons unrelated to sanctions, or what may be called nonsanction exits. Since 2001, nonsanction exits remained stable at an average of approximately 5,800 exits each month. This therefore implies that from 2000 through early 2004, more than one-third of all monthly TANF exits in Florida were due to sanctions.

Although Florida appears to rely heavily on sanctions as a policy tool, this conclusion ultimately rests on a comparison of sanction rates in Florida with sanction rates in other states. This comparison is complicated by inconsistencies in the severity of sanction policies across states. That is, in states that impose some form of partial sanction, TANF case managers may be more willing than their counterparts in Florida to issue a sanction because the consequences for TANF clients are less severe than those faced by Florida TANF clients. Still, evidence suggests that, despite the severity of Florida's sanction policy (it is the strictest allowed by federal law), sanction rates in Florida are quite high in comparison to those in other states. The most commonly reported sanction 


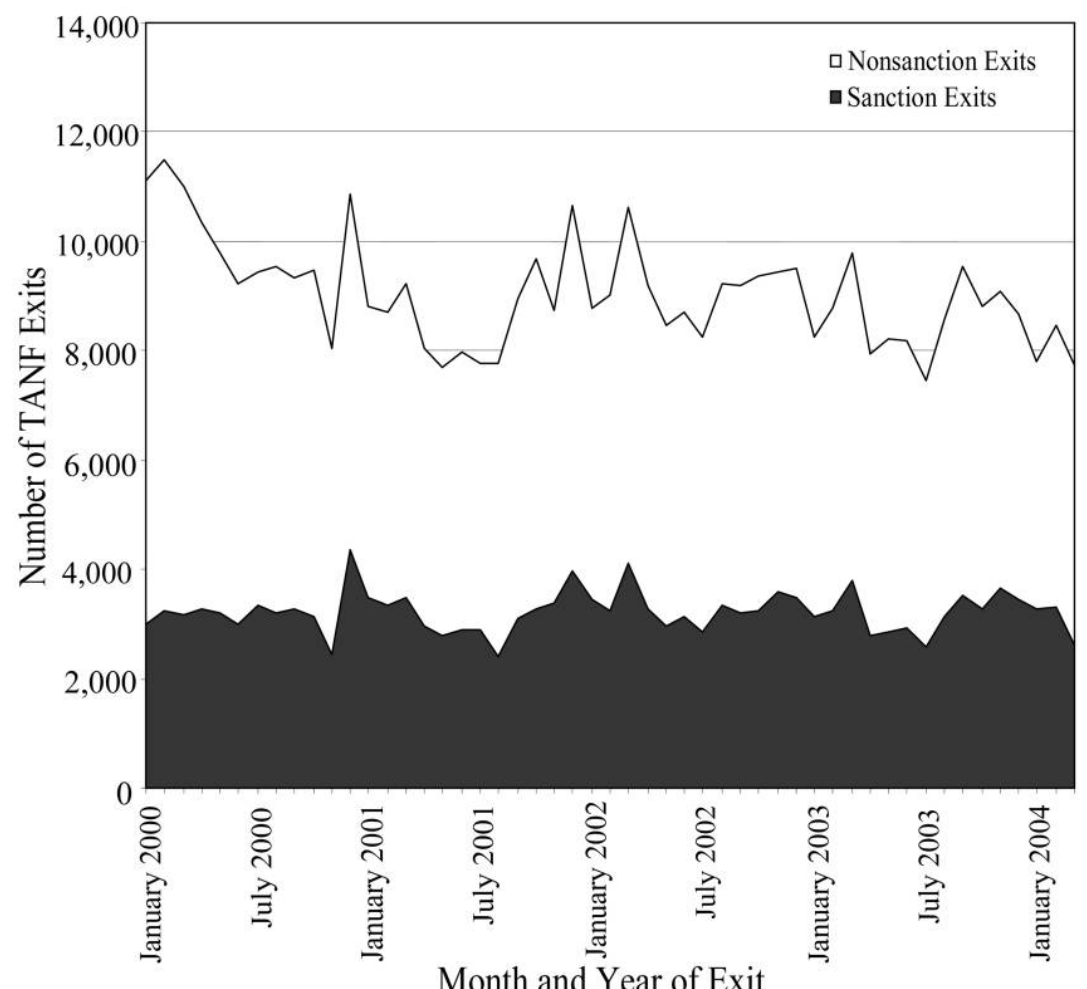

Fig. 2.-Monthly TANF (Temporary Assistance for Needy Families) exits in Florida by reason for exit, January 2000-March 2004.

statistic is the percentage of cases closed due to sanctions. As the previous discussion noted, over the period of this study, approximately onethird of all case closings in Florida were due to sanctions. In contrast, the most recent data reported by the federal government (for fiscal year 2002) show that only 7 percent of all case closings nationwide are due to sanctions (U.S. Department of Health and Human Services 2004).

Recognizing the fact that such statistics are in part a function of the number of nonsanction exits, Pavetti and associates (2004) recommend a purer measure of sanctioning that is based on the cumulative incidence of sanctioning for a panel of clients over a significant period of time. Using this method, Pavetti and associates (2004) measure the sanction rate in three states (Illinois, New Jersey, and South Carolina) that use immediate, full-family sanctions. Among those in the cohort of adult TANF recipients who entered TANF in November of 2001, after 18 months, 13 percent of the New Jersey cohort and 17 percent of the Illinois cohort were sanctioned. In South Carolina, clients could only 
be observed for 10 months. In this period, 5 percent of clients were ultimately sanctioned. Comparable sanctioning rates in Florida are estimated by relying on the same panel method used by Pavetti and colleagues (2004). Results are presented for the cohort of Florida's adult TANF recipients who entered TANF in November 2001. These indicate that, after 10 months, 43 percent of the cohort was sanctioned at least once. After 18 months, 47 percent was sanctioned. There is thus good reason to believe that Florida is among the leaders in the use of sanctions.

\section{Local Variation in Sanctioning}

To test for county variation in Florida's decentralized TANF system, county sanction rates are calculated using a method similar to the panel method advocated by Pavetti and associates (2004). However a few modifications are incorporated. First, rather than focusing on one specific cohort, the study observes sanctioning outcomes for the 24 cohorts entering TANF from January 2001 through December 2002. Second, within each cohort, observation is limited to new TANF clients; that is, the study observes clients who did not receive TANF for a minimum of 12 consecutive months prior to entering TANF. Third, the focus lies only on the first TANF spell for each cohort; a spell is defined as continuous months of TANF receipt. Finally, each cohort is examined for a maximum of 12 consecutive months. A county's sanction rate is calculated by first estimating the sanction rate for each cohort. This rate is the percentage of the cohort that exited TANF due to a sanction. The average sanction rate across the 24 cohorts is thus calculated to arrive at a final county sanction rate for each of the 66 counties in the data set.

These calculations result in a mean sanction rate of 39 percent across all 66 counties; for the 24 cohorts of new TANF clients entering TANF in 2001 and 2002, at least 39 percent were sanctioned off TANF during their first TANF spell. ${ }^{9}$ Figure 3, which displays county sanction rates for the upper and lower quartiles of the county distribution, indicates that there is much variation in county sanction rates during the study period. The figure shows that five counties display a sanction rate of less than 30 percent; Hamilton County exhibits the lowest sanction rate (22 percent) in the sample. In contrast, three counties sanctioned at a rate of at least 50 percent, with Okeechobee County displaying the highest sanction rate of all counties at 53 percent. Thus, the maximum sanction rate in this study's sample exceeded the minimum sanction rate by 141 percent. These differences are both statistically and substantively significant. They suggest that sanction implementation is carried out in fundamentally different ways across the state.

A preliminary test of the influence of the political environment on 


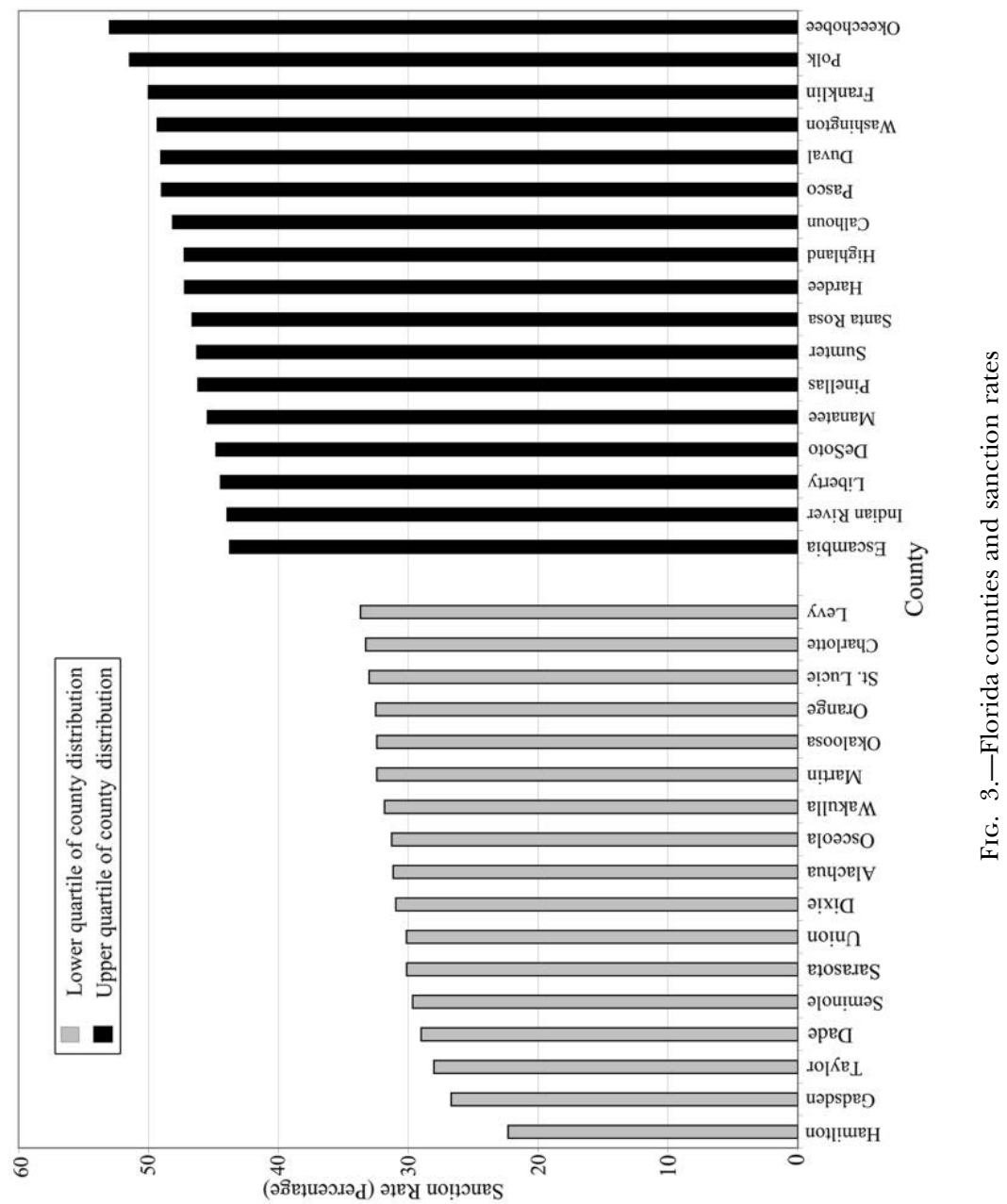




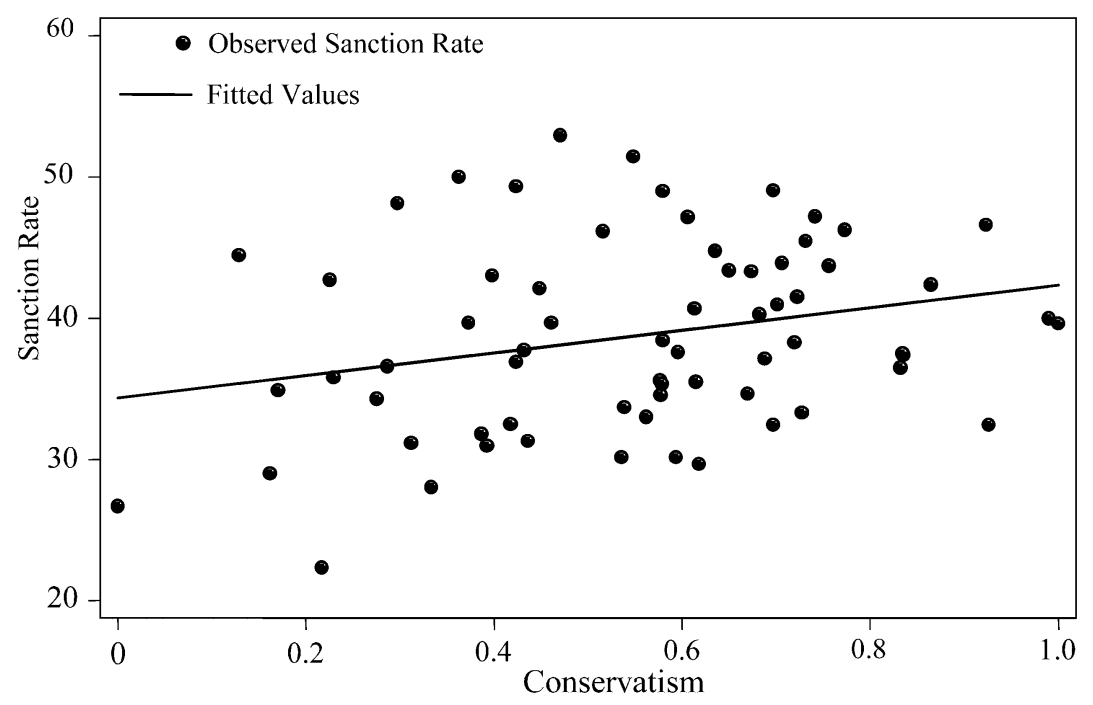

FIG. 4.-Relationship between county sanction rate and local conservatism

sanction rates is provided by examining the bivariate relationship between the local sanction rates presented in figure 3 and the index of county conservatism. This relationship, displayed in the form of a scatterplot in figure 4, provides some initial evidence of a modest relationship between local sanctioning outcomes and the political environment. This relationship is confirmed by the estimated regression line $(b=$ $8.0, p=.03)$, which is also plotted in the figure. Despite statistical significance, this relationship is clearly far from perfect and suggests that many other factors influence sanctioning outcomes. A more detailed and rigorous multivariate analysis of sanctioning is warranted.

\section{An Event History Model of Sanction Initiation}

The event history analysis uses individual-level administrative data on TANF adults. These data are provided by the Florida DCF. They are supplemented with data on county political and socioeconomic characteristics. The sample consists of all new adult clients entering TANF during the 24-month period from January 2001 through December $2002 .{ }^{10}$ Thus, the entire period of analysis extends from January 2001 (first cohort enters) through November 2003 (twelfth month of spell for last cohort). The dependent variable is dichotomous, taking on a value of one in the month that a client is sanctioned. Each member of the 24 cohorts is followed for a maximum of 12 consecutive months or until a sanction (whichever comes first). Clients who exit for reasons other than sanction, or who are not sanctioned by the twelfth month 
of the spell, are treated as right censored. For the purposes of this article, attention is restricted to each individual's first TANF spell during this period. A spell is defined as continuous months of TANF receipt. As a result of this definition and the elimination of a small percentage of cases for which data are missing, the total sample includes 60,045 individuals; this results in 169,438 person-month observations.

Estimates rely on the Cox proportional hazards model. This model allows for flexible, nonparametric estimation of the baseline hazard, or what one might think of as the effect of spell duration on the probability of sanction (Box-Steffensmeier and Jones 2004) ${ }^{11}$ For each of the variables in the model, the estimated hazard ratio is reported. This reflects the proportional change in the risk of sanction given a 1-unit increase in the independent variable of interest.

The results for the event history analysis are presented in four alternative specifications, which are listed in models $1-4$ of table $1 .{ }^{12}$ Attention for the moment is limited to model 1 , which is restricted to the effects of individual-level variables. Much as one would expect, sanctions are significantly related to various client traits. Specifically, TANF sanctions are significantly more likely to be applied to the small number of men in the program, relative to the large majority of adult women in the program. The probability of being sanctioned is negatively associated with the age of the client but positively associated with the ages of the children, higher for clients from two-parent families than for single parents, and negatively associated with human capital (as measured by wage income and education). These results are largely consistent with the findings of past studies (Born et al. 1999; Koralek 2000; Westra and Routely 2000; Mancuso and Lindler 2001; Hasenfeld et al. 2002; Kalil et al. 2002; Keiser et al. 2004; Wu et al. 2006). In addition, these relationships are largely consistent across the alternative specifications presented in table 1.

The effects of race and ethnicity are complicated; model diagnostics determined that these effects vary in magnitude across the TANF spell. ${ }^{13}$ This is especially noteworthy because, according to state officials, sanctions in the first month of a spell often result if clients register for the program and then drop out without participating. These sanctions are in effect self-imposed. Sanctions in subsequent months are initiated by caseworkers and imposed on clients who have been participating in the program. Models accordingly include multiplicative terms that multiply the race or ethnicity of the client and a simple counter variable (1-12) that represents the month of the TANF spell (e.g., black $\times$ month of spell, Hispanic $\times$ month of spell). The table presents results for the third, sixth, and ninth months of spells. Results suggest that, in the earliest months of a participation spell, white clients are significantly more likely to be sanctioned than are black or Hispanic clients. However, as the length of the spell grows, black and Hispanic clients become 
more likely than their white counterparts to experience a sanction (among Hispanic clients, the difference at the sixth and ninth month of the spell is not statistically significant). By the ninth month of the spell, black clients are predicted to be sanctioned at a rate that is anywhere from 22 to 35 percent higher than that for whites (depending upon model specification). The interaction of race and ethnicity with month of spell is extremely robust and underscores the importance of employing a longitudinal design, such as event history analysis, to study racial dynamics in TANF sanctioning.

The estimated effects of the local political climate are reflected in models 2-4. Model 2, which adds the local conservatism index to the specification presented in model 1, indicates that the risk of sanction is significantly higher in conservative counties than in liberal ones. The hazard ratio suggests that if individual traits are held constant, the risk of sanction in the most conservative county is 67 percent higher than that in the most liberal county. Model 3 adds the other contextual variables to the specification. The results suggest that local political ideology is still significantly related to sanctioning, although the estimated effect diminishes to some degree. Finally, model 4 reflects the same specification as model 3 but drops Dade County from the sample as a test of robustness. Dade County is by far the largest represented county. It includes 14 percent of all TANF clients and 16 percent of all person-month observations in the estimation sample. In many respects, Dade County is atypical among Florida's counties. Its population is racially mixed, and TANF services are delivered by a variety of different types of agencies (i.e., public, private, and nonprofit). Overall, the results for model 4 are very similar to those for model 3. This suggests that the inclusion of Dade County in the sample does not bias the overall findings. In fact, the effect of local political ideology is somewhat stronger when Dade County is removed from the sample.

Although the results presented in table 1 suggest that the effect of local political ideology is statistically as well as substantively significant, an important weakness of the hazard ratio is that it is limited to describing the relative risk of sanction at a single point in time (i.e., at a given month within the TANF spell). Further perspective on the magnitude of this effect thus is provided in figure 5, which examines the cumulative effect of local political ideology over the course of the entire TANF spell. Figure 5 plots cumulative survival rates for a typical TANF client, estimating them in two contexts (the most liberal county and the most conservative county). The figure estimates survival functions for a 31-year-old single white woman who has one child (aged 3-4 years), 12 years of education, and an average level of wage income in the quarter preceding the observed month. These estimates are based on the results presented for model 2 of table 1 . The survival curves indicate that in a conservative county, the client's probability of surviving on welfare 


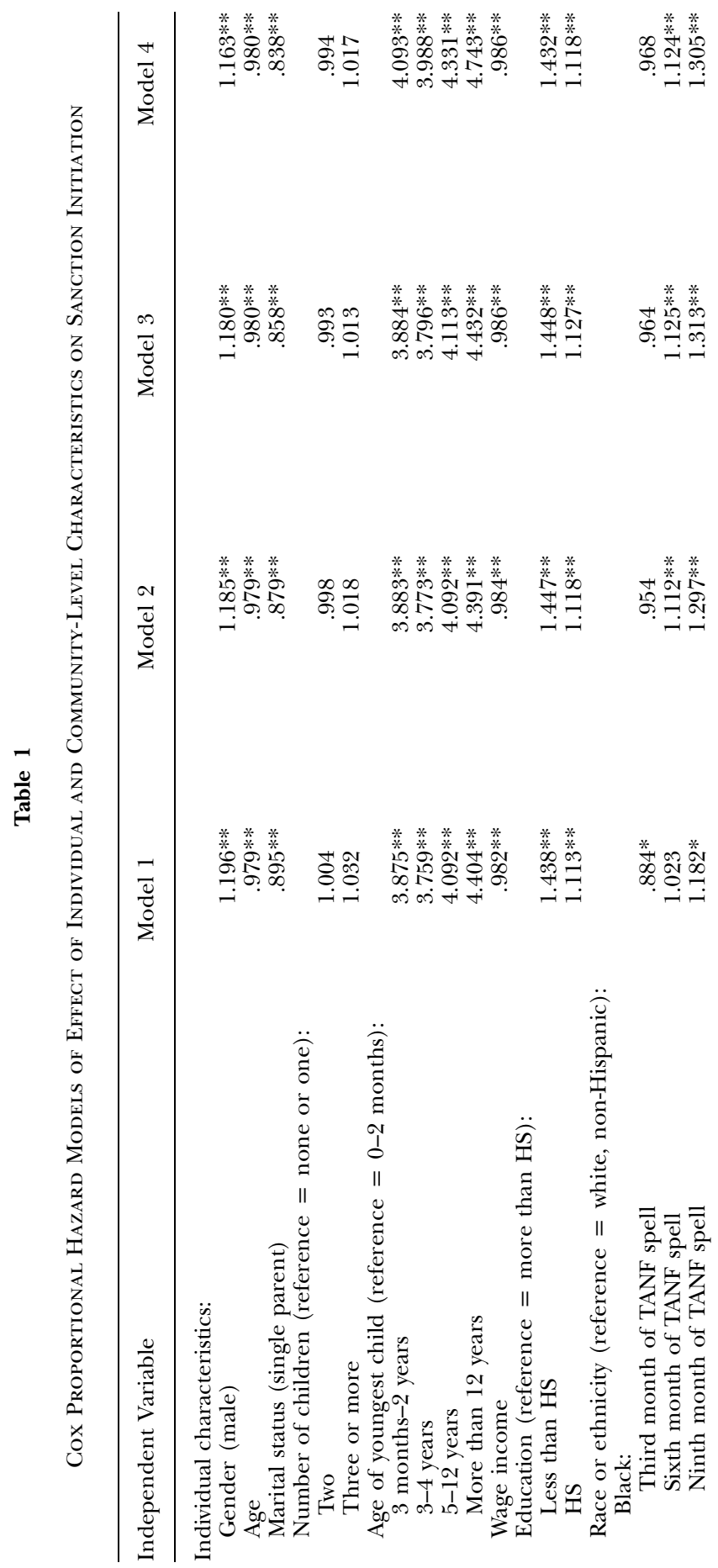




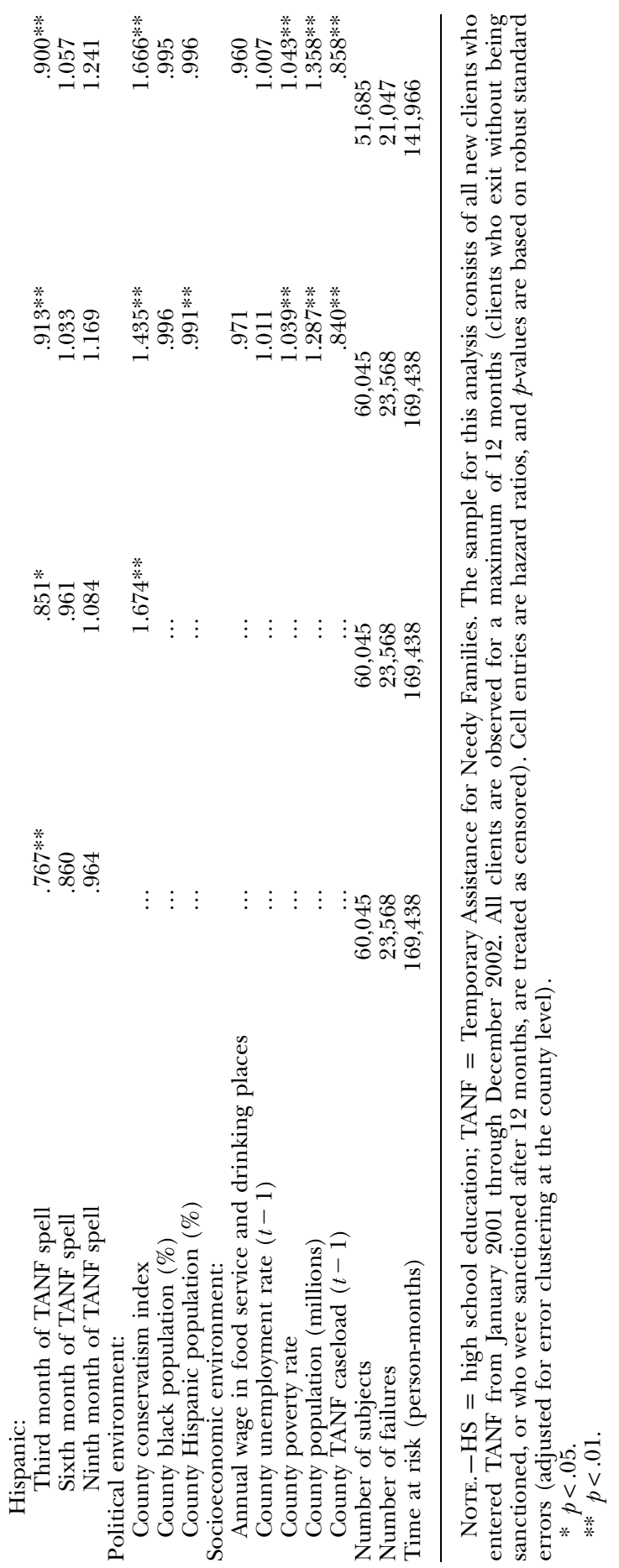




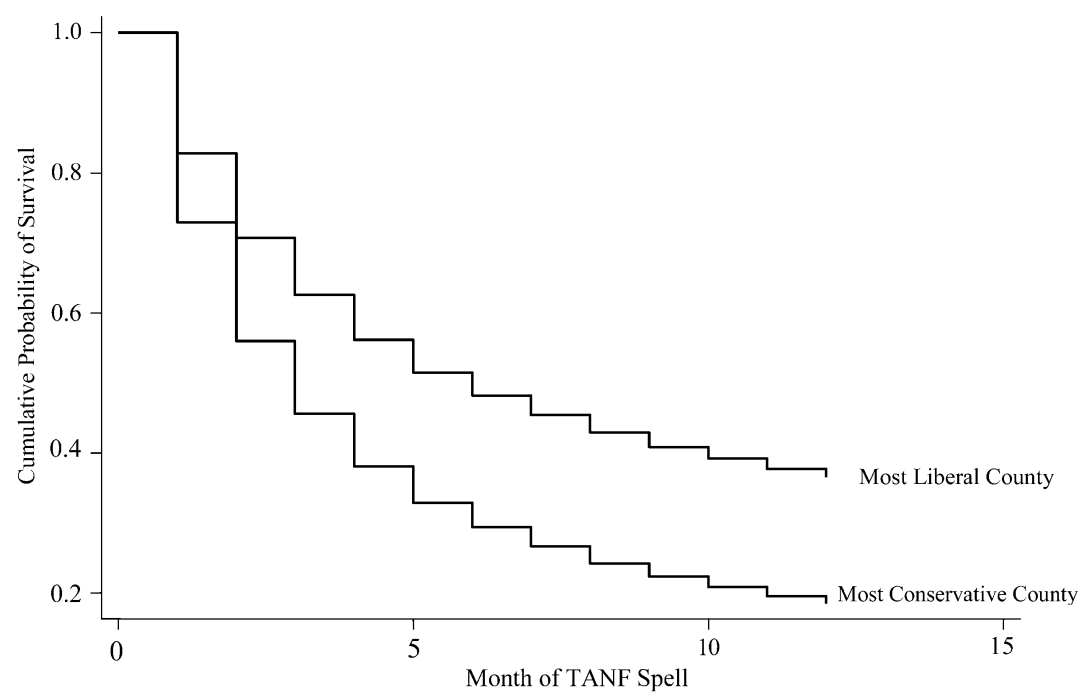

Fig. 5.-Estimated cumulative survival function for a typical TANF (Temporary Assistance for Needy Families) adult, by local political ideology. Survival functions are estimated for a 31-year-old single white woman with one child (aged 3-4 years), 12 years of education, and an average level of wage income in the previous quarter. These estimates are based on the results presented in model 2 of table 1.

through the twelfth month of a TANF spell without a sanction is approximately 0.20 . In contrast, the probability that the same (hypothetical) client will survive through the twelfth month without a sanction in the most liberal county is twice the probability of that for living in a conservative county, approximately 0.40 . Of course, very few clients in Florida experience 12-month TANF spells, but this simulation does provide additional perspective on the substantive effect of local political ideology on sanctioning outcomes.

The estimated effects of the local racial or ethnic context on sanctions provide some evidence that sanctioning is lower in areas with a large minority population than it is in areas with relatively smaller minority populations. This provides possible support for the notion that racial and ethnic minorities are able to exert influence over TANF policy outcomes. But the data do not enable a determination of whether this estimated relationship is due to indirect pressure that members of minority populations exert on TANF officials or to representation of members of these populations among case managers and TANF administrators. The coefficient for percentage of the county population that is Hispanic reaches statistical significance in model 3. However, if Dade County is dropped from the sample, this coefficient falls just below the threshold for significance. The coefficient for the percentage of the 
county population that is black is consistently negative. It does not reach the 0.05 threshold for statistical significance in any specification, but it consistently comes close to significance in each model of table $1(.10<$ $p<.20$, two-tailed).

The results in table 1 suggest that sanctioning outcomes are also influenced by the socioeconomic environment in which TANF is implemented. If all other factors are equal, the risk of sanction is estimated to be greater in large urban counties than in smaller nonurban counterparts. The higher risk may be related to the relatively higher rates of poverty. These results may reflect the effects of environments in which jobs are scarce. They may also stem from other reasons specific to the local environment. Such local factors may make it difficult for TANF clients to meet the demands of the program. It is interesting to note that the size of the TANF caseload is negatively related to sanctioning. This lends some support to the possibility that case managers with heavy caseloads have limited time to spend monitoring their clients or that they find it difficult to follow through with the administrative burden of the sanction process. Contrary to expectations, there are relatively weak estimated effects of two aspects of local labor markets; neither unemployment rates nor local wage levels prove to be a statistically significant predictor of sanctions.

\section{Conclusion}

Within the TANF program, sanction policies are a key tool for signaling to clients that they must take seriously the welfare-to-work philosophy and the slate of obligations it imposes. If clients do not meet their obligations, they lose access to cash assistance. Because sanctioning has important implications for clients' well-being, a number of studies examine the determinants of sanctioning. Although these studies further understanding, they are almost exclusively client-centered in theoretical approach, neglecting to consider other factors, including the role of local political ideology in conditioning the implementation of sanction policies. The current analysis examines local variation in sanctioning across the state of Florida, which is an innovator among states in developing a decentralized system for administering welfare reform. Three findings seem to merit special attention.

First, several studies show that the discretion granted to states through first-order devolution is used to tailor state welfare programs to the ideological tastes of their citizens (e.g., Soss et al. 2001; Fellowes and Rowe 2004). Welfare reform, however, also is characterized by secondorder devolution, which increases the importance of local discretion in welfare reform outcomes. The current analysis suggests that, at least in one state, second-order devolution may indeed further allow policies to be shaped by ideology. The analysis of sanctioning presented in Florida 
thus shows that there is much variation in local sanctioning practices; this variation persists even after controlling for individual client traits. More important, there is strong evidence that local differences are tied to local political values. The causal mechanism that drives this finding is not clear; however, there is good reason to believe it is rooted in the decentralized nature of the state's TANF implementation. Under this system, there is a potential for local policy makers, agency managers, and case managers to exercise influence over the implementation of sanctions above and beyond the influence they could exert under a less decentralized system. To the extent that local political ideology does in fact shape local implementation decisions, this finding raises important questions about decentralization's potential effectiveness in achieving the goals of welfare reform (Cho et al. 2005).

A second important finding is that social class influences sanctioning outcomes. This study is consistent with prior research in finding that individuals with low levels of human capital (as indicated by low education and income levels) are associated with being sanctioned. There also is evidence that class exhibits a contextual effect, in that the probability of sanction is high among clients who live in poverty-stricken areas. As many of the most disadvantaged TANF clients are likely to live in areas characterized by a high concentration of poverty, this finding suggests that many poor families may be doubly disadvantaged in their efforts to comply with the demands placed upon them by the welfare system.

Finally, the findings concerning the relationship between race and sanctioning suggest that the phenomenon of racial disparities may be more complex than has been thus far understood. This complexity is demonstrated by two sets of findings. First, both the magnitude and the direction of racial disparity in sanctioning are strongly related to the duration of the TANF spell. This time dependency is most evident in examining black-white disparities but can also be seen to some extent in examining Hispanic-white disparities. Second, the magnitude of racial disparities increases if one controls for community characteristics. Together, these findings highlight the importance of using a methodological approach to studying sanctions that relies on an event history design and also considers the effects of the local implementation environment.

In conclusion, these findings raise questions about the prevailing tendency to interpret cross-client variation in the probability of being sanctioned as a product of individual-level differences, independent of contextual factors such as the political environment. The evidence presented in this study suggests otherwise. For clients, the probability of being sanctioned is highly dependent upon whether welfare-to-work participation is occurring in a liberal or conservative political environment. Sanction implementation is not a politically neutral process, at least not in a state 
that decentralizes the administration of welfare. The political values that prevail in local environments matter for the frequency and incidence of sanctioning. When viewed alongside this study's findings for human capital and client race, the political character of sanctioning should raise significant concerns for scholars and policy makers alike. 


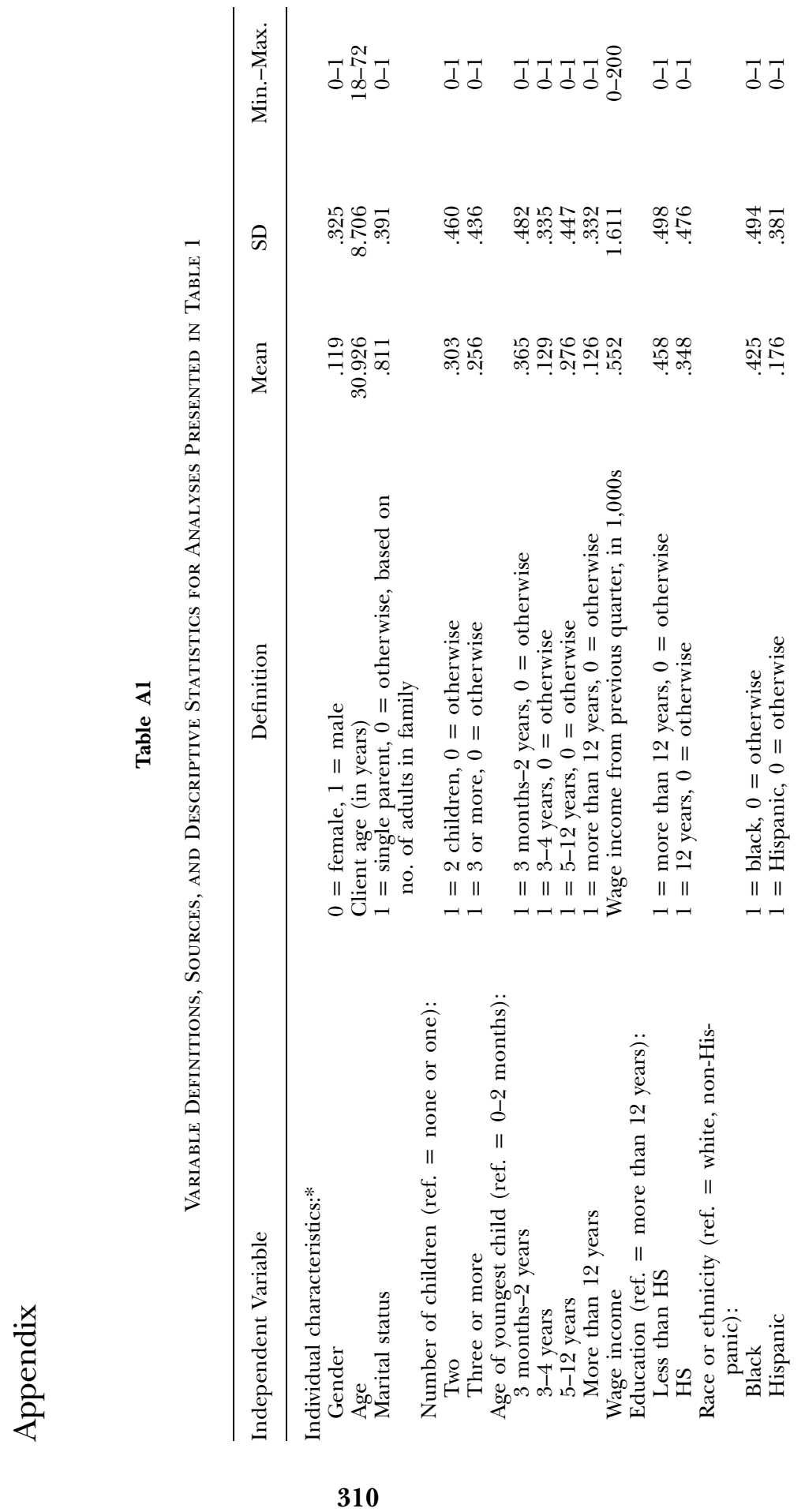




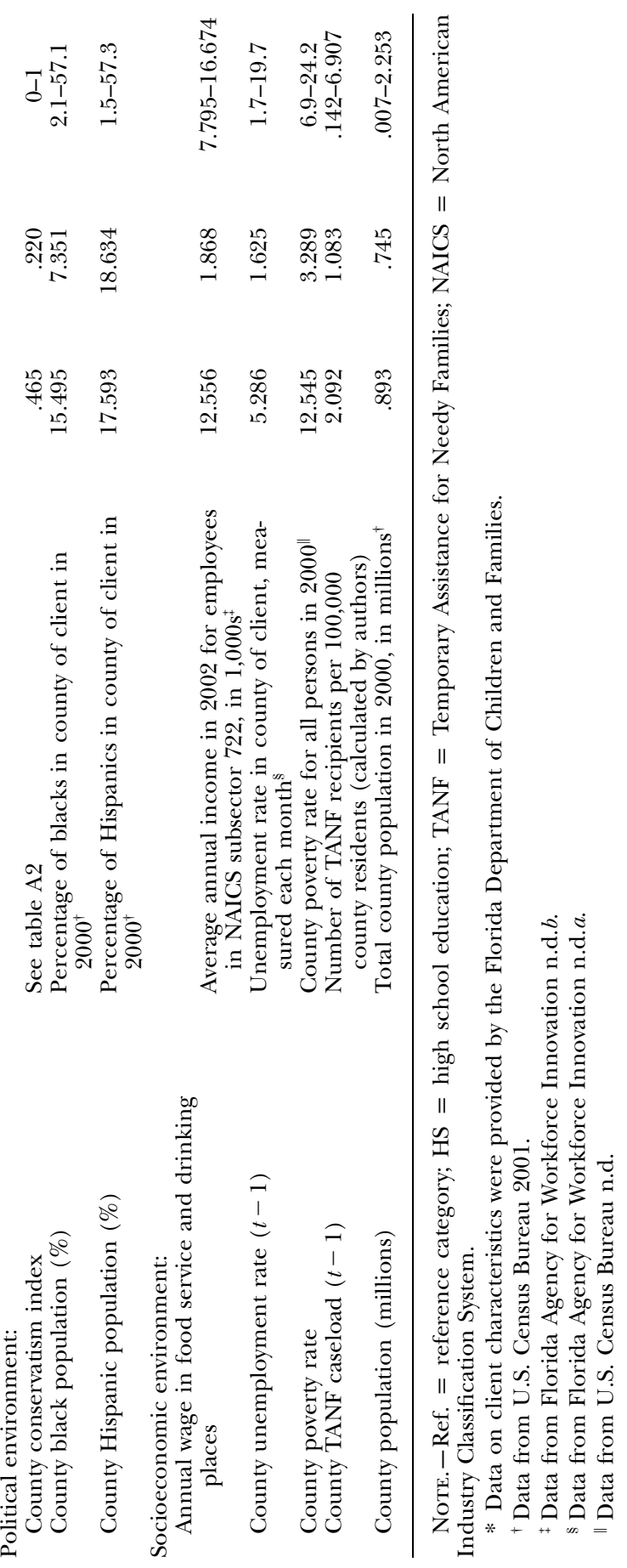

311 
Table A2

Construction of Index of County Political Ideology

\begin{tabular}{|c|c|c|c|}
\hline Ballot Title & $\begin{array}{l}\text { Election } \\
\text { Year }\end{array}$ & $\begin{array}{l}\text { Ballot } \\
\text { Number }\end{array}$ & $\begin{array}{l}\text { To Amend } \\
\text { Florida State } \\
\text { Constitution }\end{array}$ \\
\hline \multicolumn{4}{|l|}{ Should Two-Thirds Vote be Required for } \\
\hline New Constitutionally-Imposed State & & & \\
\hline Taxes/Fees? & 1996 & Con. Am. 1 & Art. XI, sec. 7 \\
\hline Fee on Everglades Sugar Production & 1996 & Con. Am. 4 & Art. VII, sec. 9 \\
\hline \multicolumn{4}{|l|}{ Responsibility for Paying Costs for Water } \\
\hline Pollution Ábatement in the Everglades & 1996 & Con. Am. 5 & Art. II, sec. 7 \\
\hline \multicolumn{4}{|l|}{ Preservation of the Death Penalty: United } \\
\hline $\begin{array}{l}\text { States Supreme Court Interpretation of } \\
\text { Cruel and Unusual Punishment }\end{array}$ & 1998 & Con. Am. 2 & Art. I, sec. 17 \\
\hline Additional Homestead Tax Exemption & 1998 & Con. Am. 3 & Art. VII, sec. 6 \\
\hline Public Education of Children & 1998 & Con. Am. 6 & Art. IX, sec. 1 \\
\hline Basic Rights & 1998 & Con. Am. 9 & Art. I, sec. 2 \\
\hline $\begin{array}{l}\text { Ballot Access, Public Campaign Financing, } \\
\text { and Election Process Revisions }\end{array}$ & 1998 & Con. Am. 11 & $\begin{array}{l}\text { Art. IV, sec. 5a; } \\
\text { Art. VI, secs. } \\
\text { 1, } 2,5,7 ; \text { Art. } \\
\text { IX, sec. } 4 \mathrm{a}\end{array}$ \\
\hline \multicolumn{4}{|l|}{$\begin{array}{l}\text { Firearms Purchases: Local Option for Crimi- } \\
\text { nal History Records Check and Waiting }\end{array}$} \\
\hline $\begin{array}{l}\text { Florida Transportation Initiative for State- } \\
\text { wide High Speed Monorail, Fixed Guide- } \\
\text { way of Magnetic Levitation System }\end{array}$ & 2000 & Con. Am. 1 & Art. X, sec. 19 \\
\hline $\begin{array}{l}\text { Protect People from the Health Hazards of } \\
\text { Second-Hand Tobacco Smoke by Prohibit- } \\
\text { ing Workplace Smoking }\end{array}$ & 2002 & Con. Am. 6 & Art. X, sec. 20 \\
\hline \multicolumn{4}{|l|}{ Voluntary Universal Pre-kindergarten } \\
\hline Education & 2002 & Con. Am. 8 & Art. IX, sec. 1 \\
\hline Florida's Amendment to Reduce Class Size & 2002 & Con. Am. 9 & Art. IX, sec. 1 \\
\hline \multicolumn{3}{|l|}{$\begin{array}{l}\text { Animal Cruelty Amendment: Limiting Cruel } \\
\text { and Inhumane Confinement of Pigs dur- }\end{array}$} & Art. X, sec. 19 \\
\hline \multicolumn{3}{|l|}{ Parental Notification of a Minor's Termina- } & Art. X, sec. 22 \\
\hline Florida Minimum Wage Amendment & 2004 & Con. Am. 5 & Art. $\mathrm{X}$ \\
\hline $\begin{array}{l}\text { The Medical Liability Claimant's Compensa- } \\
\text { tion Amendment }\end{array}$ & 2004 & Con. Am. 3 & Art. I, sec. 26 \\
\hline Authorizes Miami-Dade and Broward & & & \\
\hline $\begin{array}{l}\text { County Voters to Approve Slot Machines } \\
\text { in Parimutuel Facilities }\end{array}$ & 2004 & Con. Am. 4 & Art. X, sec. 19 \\
\hline
\end{tabular}

Note.-Con. Am. = constitutional amendment. The index of local ideology is constructed from data on 18 ideologically relevant constitutional amendments that appeared on Florida's statewide ballot for ratification at some point from 1996 through 2004. The percentage of votes in favor of each amendment is computed for each county. A factor analysis is then conducted using all 18 amendments (thus 18 variables, $N=67$ counties). The amendments are identified in the table. 


\section{References}

$\rightarrow$ Barrilleaux, Charles, Thomas Holbrook, and Laura Langer. 2002. "Electoral Competition, Legislative Balance, and American State Welfare Policy." American Journal of Political Science 46 (2): 415-27.

Blalock, Hubert M. 1967. Toward a Theory of Minority Group Relations. New York: Wiley.

Born, Catherine E., Pamela J. Caudill, and Melinda L. Cordero. 1999. "Life after Welfare: A Look at Sanctioned Families." Report. University of Maryland, School of Social Work, Welfare, and Child Support Research and Training Group, Baltimore.

Botsko, Christopher, Kathleen Snyder, and Jacob Leos-Urbel. 2001. "Recent Changes in Florida Welfare and Work, Child Care, and Child Welfare Systems." New Federalism: National Survey of America's Families, State Update no. 2. Urban Institute, Washington, DC.

Box-Steffensmeier, Janet M., and Bradford S. Jones. 2004. Event History Modeling: A Guide for Social Scientists. Cambridge: Cambridge University Press.

CBS News/New York Times. 2002. "CBS News/New York Times Florida State Poll, October 2000.” Computer file ICPSR 3223. Inter-university Consortium for Political and Social Research, Ann Arbor, MI.

$\rightarrow$ Cho, Chung-Lae, Christine A. Kelleher, Deil S. Wright, and Susan Webb Yackee. 2005. "Translating National Policy Objectives into Local Achievements across Planes of Governance and among Multiple Actors: Second-Order Devolution and Welfare Reform Implementation." Journal of Public Administration Research and Theory 15 (1): 31-54.

Cook, Fay Lomax, and Edith J. Barrett. 1992. Support for the American Welfare State: The Views of Congress and the Public. New York: Columbia University Press.

$\rightarrow$ Dias, Janice Johnson, and Steven Maynard-Moody. 2007. "For-Profit Welfare: Contracts, Conflicts, and the Performance Paradox." Journal of Public Administration Research and Theory 17 (2): 189-211.

Eggers, William D., and John O'Leary. 1995. Revolution at the Roots: Making Our Government Smaller, Better, and Closer to Home. New York: Free Press.

$\rightarrow$ Ewalt, Jo Ann G., and Edward T. Jennings Jr. 2004. "Administration, Governance, and Tools in Welfare Policy Implementation.” Public Administration Review 64 (4): 449-62.

Feldman, Martha S. 1989. Order without Design: Information Production and Policy Making. Stanford, CA: Stanford University Press.

- 1992. "Social Limits to Discretion: An Organizational Perspective." 163-84 in The Uses of Discretion, edited by Keith Hawkins. Oxford: Clarendon.

$\rightarrow$ Fellowes, Matthew C., and Gretchen Rowe. 2004. "Politics and the New American Welfare States." American Journal of Political Science 48 (2): 362-73.

Florida Agency for Workforce Innovation. n.d.a. Florida Research and Economic Database. http:/ / fred.labormarketinfo.com (accessed July 2005)

_ n.d.b. "QCEW-Quarterly Census of Employment and Wages (ES-202)." Labor Market Statistics Library database. http://www.labormarketinfo.com/library/qcew .htm (accessed July 2005).

$\rightarrow$ Fording, Richard C. 1997. "The Conditional Effect of Violence as a Political Tactic: Mass Insurgency, Welfare Generosity, and Electoral Context in the American States." American Journal of Political Science 41 (1): 1-29.

$\rightarrow$ Gainsborough, Juliet F. 2003. "To Devolve or Not to Devolve? Welfare Reform in the States." Policy Studies Journal 31 (4): 603-23.

Gais, Thomas L., and R. Kent Weaver. 2002. "State Policy Choices under Welfare Reform." Policy Brief no. 21. Brookings Institution, Washington, DC.

Goggin, Malcolm L., Ann Bowman, James Lester, and Laurence O’Toole. 1990. Implementation Theory and Practice: Toward a Third Generation. New York: Scott Foresman.

Goldberg, Heidi, and Liz Schott. 2000. "A Compliance-Oriented Approach to Sanctions in State and County TANF Programs." Report. Center on Budget and Policy Priorities, Washington, DC.

Handler, Joel F. 1992. "Discretion: Power, Quiescence, and Trust." 331-60 in The Uses of Discretion, edited by Keith Hawkins. Oxford: Clarendon.

Hart, H. L. A. 1961. The Concept of Law. Oxford: Clarendon.

$\rightarrow$ Hasenfeld, Yeheskel. 1987. "Power in Social Work Practice." Social Service Review 61 (3): 469-83. 


\section{Social Service Review}

Hasenfeld, Yeheskel, Toorjo Ghose, and Kandyce Hillesland-Larson. 2002. "At Risk of Being Sanctioned: Comparing Sanctioned and Non-sanctioned Welfare Recipients in California's CalWORKS." Paper presented at the 24th Annual Fall Research Conference of the Association for Public Policy Analysis and Management, November 7-9, Dallas.

$\rightarrow$ Hasenfeld, Yeheskel, and Lisa Evans Powell. 2004. "The Role of Non-profit Agencies in the Provision of Welfare-to-Work Services." Administration in Social Work 28 (3-4): 91-110.

Herzfeld, Michael. 1992. The Social Production of Indifference: Exploring the Symbolic Roots of Western Bureaucracy. New York: St. Martin's.

$\rightarrow$ Kalil, Ariel, Kristin S. Seefeldt, and Hui-chen Wang. 2002. "Sanctions and Material Hardship under TANF." Social Service Review 76 (4): 642-62.

Kane, James G. 2004. "Florida Voter Panel Study, 1999." Computer file ICPSR03435-v1. Inter-university Consortium for Political and Social Research, Ann Arbor, MI.

Keech, William R. (1968) 1981. The Impact of Negro Voting: The Role of the Vote in the Quest for Equality. Reprint. Westport, CT: Greenwood.

$\rightarrow$ Keiser, Lael R. 1999. "State Bureaucratic Discretion and the Administration of Social Welfare Programs: The Case of Social Security Disability." Journal of Public Administration Research and Theory 9 (1): 87-106.

$\rightarrow$ Keiser, Lael R., Peter R. Meuser, and Seung-Whan Choi. 2004. "Race, Bureaucratic Discretion, and the Implementation of Welfare Reform." American Journal of Political Science 48 (2): 314-27.

$\rightarrow$ Keiser, Lael R., and Joe Soss. 1998. "With Good Cause: Bureaucratic Discretion and the Politics of Child Support Enforcement." American Journal of Political Science 42 (4): 1133-56.

Key, V. O., Jr. 1949. Southern Politics in State and Nation. New York: Knopf.

Koralek, Robin. 2000. "South Carolina Family Independence Program Process Evaluation." Report to the South Carolina Department of Social Services. Urban Institute, Washington, DC.

Lipsky, Michael. 1978. "Standing the Study of Public Policy Implementation on Its Head." 391-402 in American Politics and Public Policy, edited by Walter Dean Burnham and Martha Wagner Weinberg. MIT Studies in Politics and Policy, no. 4. Cambridge, MA: MIT Press.

. 1980. Street-Level Bureaucracy: Dilemmas of the Individual in Public Services. New York: Russell Sage.

Lurie, Irene. 2006. At the Front Lines of the Welfare System: A Perspective on the Decline in Welfare Caseloads. Albany, NY: State University of New York, Rockefeller Institute of Government.

Maloy, Kathleen A., LaDonna A. Pavetti, Peter Shin, Julie Darnell, and Lea ScarpullaNolan. 1998. "A Description and Assessment of State Approaches to Diversion Programs and Activities under Welfare Reform." Unpublished report. George Washington University, Center for Health Policy Research, Washington, DC.

Mancuso, David C., and Vanessa L. Lindler. 2001. "Examining the Circumstances of Welfare Leavers and Sanctioned Families in Sonoma County: Final Report." Report to the Sonoma County, CA, Human Services Department. SPHERE Institute, Burlingame, CA.

Martin, Joanne. 1992. Cultures in Organizations: Three Perspectives. New York: Oxford University Press.

$\rightarrow$ Maynard-Moody, Steven, and Michael C. Musheno. 2000. "State Agent or Citizen Agent: Two Narratives of Discretion." Journal of Public Administration Research and Theory 10 (2): $329-58$.

- 2003. Cops, Teachers, Counselors: Stories from the Front Lines of Public Service. Ann Arbor: University of Michigan Press.

Mead, Lawrence M. 2000. "Governmental Quality and Welfare Reform." Paper presented at the 2000 Annual Meeting of the American Political Science Association, September 1 , Washington, DC.

Meier, Kenneth J. 2000. Politics and the Bureaucracy: Policymaking in the Forth Branch of Government. 4th ed. Fort Worth, TX: Harcourt.

Meyers, Marcia K., Shannon Harper, Marieka Klawitter, and Taryn Lindhorst. 2006. "Review of Research on TANF Sanctions." Report to Washington State WorkFirst SubCabinet. University of Washington, West Coast Poverty Center, Seattle. 
$\rightarrow$ Meyers, Marcia K., Norma M. Riccucci, and Irene Lurie. 2001. "Achieving Goal Congruence in Complex Environments: The Case of Welfare Reform." Journal of Public Administration Research and Theory 11 (2): 165-201.

Miller, Warren E. 1999. "Temporal Order and Causal Inference." Political Analysis 8 (2): $119-46$.

Mink, Gwendolyn. 2002. "Violating Women: Rights Abuses in the Welfare Police State." 95-112 in Lost Ground: Welfare Reform, Poverty, and Beyond, edited by Randy Albelda and Ann Withorn. Cambridge, MA: South End.

$\rightarrow$ Morgen, Sandra. 2001. "The Agency of Welfare Workers: Negotiating Devolution, Privatization, and the Meaning of Self-Sufficiency." American Anthropologist 103 (3): 747-61.

Nathan, Richard P. 1996. "The 'Devolution Revolution': An Overview." Rockefeller Institute Bulletin (State University of New York, Rockefeller Institute of Government, Albany) 1996:5-13.

Nathan, Richard P., and Thomas L. Gais. 1999. Implementing the Personal Responsibility Act of 1996: A First Look. Albany: State University of New York, Rockefeller Institute of Government.

Pavetti, LaDonna A., Michelle K. Derr, and Heather Hesketh. 2003. "Review of Sanction Policies and Research Studies: Final Literature Review.” Report to the U.S. Department of Health and Human Services, Office of the Assistant Secretary for Planning and Evaluation, March 10. Mathematica Policy Research, Washington, DC.

Pavetti, LaDonna A., Michelle K. Derr, Gretchen Kirby, Robert G. Wood, and Melissa A. Clark. 2004. "The Use of TANF Work-Oriented Sanctions in Illinois, New Jersey, and South Carolina: Final Report." Report to the U.S. Department of Health and Human Services, Office of the Assistant Secretary for Planning and Evaluation (contract no. 100-01-0011). Mathematica Policy Research, Washington, DC.

Prottas, Jeffrey M. 1979. People-Processing: The Street-Level Bureaucrat in Public Service Bureaucracies. Lexington, MA: Lexington.

Ragin, Charles C. 2000. Fuzzy-Set Social Science. Chicago: University of Chicago Press.

Rector, Robert E., and Sarah E. Youssef. 1999. "The Determinants of Welfare Caseload Decline." Report no. 99-04. Heritage Foundation, Washington, DC.

$\rightarrow$ Riccucci, Norma M. 2005. "Street-Level Bureaucrats and Intrastate Variation in the Implementation of Temporary Assistance for Needy Families Policies." Journal of Public Administration Research and Theory 15 (1): 89-111.

Ridzi, Frank. 2004. "Making TANF Work: Organizational Restructuring, Staff Buy-In, and Performance Monitoring in Local Implementation." Journal of Sociology and Social Welfare 31 (2): 27-48.

Shaw, Kathleen M., Sara Goldrick-Rab, Christopher Mazzeo, and Jerry A. Jacobs. 2006. Putting Poor People to Work: How the Work-First Idea Eroded College Access for the Poor. New York: Russell Sage.

Soss, Joe. 2000. Unwanted Claims: The Politics of Participation in the U.S. Welfare System. Ann Arbor: University of Michigan Press.

$\rightarrow$ Soss, Joe, Sanford F. Schram, Thomas P. Vartanian, and Erin O’Brien. 2001. "Setting the Terms of Relief: Explaining State Policy Choices in the Devolution Revolution." American Journal of Political Science 45 (2): 378-95.

U.S. Census Bureau. 2001. County and City Data Book: 2000. 13th ed. Washington, DC: U.S. Census Bureau.

- n.d. Small Area Income and Poverty Estimates. http://www.census.gov/hhes/www/ saipe/index.html (accessed July 2005).

U.S. Department of Health and Human Services, Administration for Children and Families, Office of Family Assistance. 2004. Temporary Assistance for Needy Families (TANF): Sixth Annual Report to Congress. Report, November. U.S. Department of Health and Human Services, Administration for Children and Families, Office of Family Assistance, Washington, DC.

$\rightarrow$ Weissert, Carol S. 1994. "Beyond the Organization: The Influence of Community and Personal Values on Street-Level Bureaucrats' Responsiveness." Journal of Public Administration Research and Theory 4 (2): 225-54.

- ed. 2000. Learning from Leaders: Welfare Reform Politics and Policy in Five Midwestern States. Albany, NY: State University of New York, Rockefeller Institute of Government.

Westra, Karen L., and John Routely. 2000. "Arizona Cash Assistance Exit Study: First Quarter 1998 Cohort.” Report. Arizona Department of Economic Security, Phoenix. 
Wu, Chi-Fang, Maria Cancian, Daniel R. Meyer, and Geoffrey Wallace. 2006. "How Do Welfare Sanctions Work?” Social Work Research 30 (1): 33-50.

Yin, Robert K. 2003. Case Study Research: Design and Methods. 3rd ed. Newbury Park, CA: Sage.

\section{Notes}

This research has been supported by the University of Kentucky Center for Poverty Research (UKCPR), the Institute for Research on Poverty at the University of Wisconsin-Madison, the Center on Ethnicities, Communities, and Social Policy at Bryn Mawr College, and the Annie E. Casey Foundation. The authors are grateful to representatives of the Florida Department of Children and Families and Workforce Florida Inc. for the data used in this article and to Adam Butz for valuable research assistance. The opinions and conclusions expressed herein are solely those of the authors and should not be construed as representing the opinions or policy of the UKCPR or any agency of the federal government.

1. Exemptions for good cause vary across the states but typically include illness, the need to care for a sick family member, and lack of child care (Pavetti et al. 2004).

2. Administrative data for Glades County are unavailable.

3. Detailed variable descriptions, including data sources and descriptive statistics for each variable used, are provided in appendix table Al.

4. Florida classifies a very small percentage (less than 2 percent) of clients' race as "other." These individuals are omitted from the sample. Analysis is restricted to citizens due to the unique challenges faced by noncitizens on TANF.

5. A list of the subjects of these amendments is presented in table A2.

6 . The measure of the Republican vote share is the two-party vote share in the presidential elections of 1996, 2000, and 2004.

7. The surveys used to create these scores were the Florida Voter Panel Study conducted in 1999 (Kane 2004) and a CBS News/New York Times survey of Florida voters conducted in 2000 (CBS News/New York Times 2002). The average sample size for the eight counties used in this analysis is 95 .

8. This study examines wages for workers in food service and drinking establishments because these jobs are common among the unskilled workers, mostly women, who rely on public assistance.

9. As these calculations are based on a maximum spell of 12 months, the first spell sanction rate is underestimated to the extent that clients were sanctioned after 12 months. However, results indicate that spells of more than 12 consecutive months are extremely rare in Florida.

10. This article defines "new" TANF clients as those clients who have spent at least 12 continuous months without TANF benefits.

11. The findings are replicated using other estimation methods as well, including parametric methods (Weibull) and a discrete-time (logit) model.

12. Given the multilevel character of the data, the $p$-values reported in table 1 are based on standard errors that are adjusted for error correlation within counties.

13. Specifically, analyses examine the interaction of client race or ethnicity with alternative measures of the month of the TANF spell (linear, nonlinear, and dummy variable versions). All analyses found a statistically significant interaction between race or ethnicity of client and month of spell. For the sake of parsimony, the results report an interaction between race or ethnicity of client and a linear version of the month of the TANF spell. 